\title{
Food allergy in migraine
}

\section{By Jean A. Monro, National Hospital for Nervous Diseases, Queen Square, London $W C_{1}$}

There is a long history associating food allergy with migraine which has been reviewed recently (Monro, 1982). In all, seventeen studies were reported involving investigations on over 1236 patients. The diagnostic methods used to define allergy were mainly elimination diets and challenge and skin tests. Two specific cases, however, are worth emphasizing. Goltman (1936) reported the case of a woman who was operated on during an attack of migraine. Her brain was found to be oedematous but no other abnormality was found. Later, when given wheat, similar oedema was palpable through the skull opening. Another report is of a patient subject to migraine who contracted mumps and thereafter had electromyographic evidence of weakness in the left quadriceps muscle when challenged with a known allergen, egg (Kailin \& Hastings, 1970).

The diagnosis of migraine is used interchangeably with vascular headaches. It includes the categories of common, classical, hemiplegic and ophthalmoplegic migraines and cluster headache, the latter being segregated by some into a different category and termed migrainous neuralgia. The clinical syndromes are distinct at the time but individuals subject to one type may get another type at other periods.

In common migraine, periodic headaches occur accompanied sometimes by nausea and dizziness. Classical migraine is a much more fulminating condition with unilateral hemicranial headache giving its name to the condition. It is a complex symptom in which headache predominates and may last from a few hours to a few days and in which visual disturbances precede the headache. Teichopsia with scintillating scotomata occurs with perhaps a heightened perception of sound or scent and photophobia. Then nausea and vomiting, constipation or diarrhoea, urinary retention followed by diuresis, complaints of feeling cold and associated pallor may occur. When sensory disturbances such as unilateral tingling, numbness and weakness occur on the contralateral side to that of the headache the condition is termed hemiplegic migraine and indeed the headaches may lead to permanent hemiplegic signs or disturbances of speech. Ophthalmoplegic migraine is another variant in which ocular palsies occur associated with the headaches-they are usually unilateral third nerve palsies and are generally transient. Horton's neuralgia and histamine headache are synonyms for cluster headache. The diathesis is somewhat different from the other forms of migraine as it occurs in phases or clusters with recurrent attacks followed by an interval of remission which can be prolonged. The headache is often extremely severe and conforms to the distribution of the external carotid artery. Accompanying the headache is a profuse 
lacrimation and conjunctivitis, rhinorrhoea, perspiration and vasodilatation. Males more commonly suffer from this than females, by a ratio of $5: 1$.

There have been various theories as to the pathophysiology of migraine. The initial aura in classical migraine corresponds to a period of cerebral anoxia, which has been shown to occur by the examination of the cerebrospinal fluid in migraineurs (Welch, 1976).

The symptoms of the aura suggest focal cerebral ischaemia but the reduction in cerebral blood flow has been shown to be diffuse though most pronounced in the clinically involved area. The ischaemia may outlast the clinical manifestations of the aura (Edmeads, 1977). During the headache phase the patient has increased blood flow to the brain and scalp and some oedema of the brain, as has already been mentioned. This may be a compensatory effect from the hypoxia or it could be that pain itself augments metabolism, causing the blood flow to increase (Ingvar, 1976).

We have investigated the incidence of food allergy in migraine, both by dietary elimination and by a radio-allergo sorbent test (RAST). It has been shown that provided the RAST is interpreted as an individual profile of specific IgE, rather than of an average score, the results can be helpful in indicating food allergy (Monro et al. 1980). However, management of patients on a complex elimination diet has proved difficult and we have therefore pursued intradermal skin testing using the method described originally by Lee and modified by Miller (1976). There is good evidence that this type of therapy works satisfactorily in food allergy, from four double-blind studies (Miller, 1977; Rapp, 1978; J. J. McGovern Jr, D. J. Rapp, J. A. Lazaroni and R. W. Gardner, unpublished results; D. E. Podell, W. J. Rea, D. E. Sprague, R. E. Smiley, A. R. Johnson, A. Lopez de Victoria, W. F. Tucker and $M$. Mitchell, unpublished results).

\section{Materials and methods}

The patients were ones who had been referred to the National Hospital for Nervous Diseases, Queen Square, London. They had previously been to their own doctors for routine therapy for migraine and had been referred to their local hospital physicians before re-referral to the National Hospital. Therefore the group of patients tested were a select group in that they often had severe, frequent attacks of migraine which were intractable or unresponsive to therapy in current usage. Furthermore, they were asked whether or not they wished to try further anti-migrainous therapy or to pursue dietary investigations. Those who chose to pursue dietary tests were, therefore, a further selected group with motivation to attempt this form of investigation. Patients who were pregnant were excluded from any investigations.

Exclusion diets. Initially, patients were asked to undertake a basic allergy regimen as follows:

I. Record daily, in duplicate, your diet and any symptoms. Also note if any drugs are taken. 
2. Record your pulse: (1) before a meal, (2) $20 \mathrm{~min}$ after a meal, (3) $40 \mathrm{~min}$ after that. This should be done in the following manner: sit quietly for $5 \mathrm{~min}$ before taking the pulse, then count the pulse for $30 \mathrm{~s}$ and multiply this figure by 2 .

3. Do NOT eat between meals and drink only spring water if you are thirsty. (Three main meals and three snacks have been allowed for.)

4. Take PLAIN FRESH FOOD and sea salt only. Vary your diet, eating only reasonable quantities as too much of anything is bad for you. Read all labels carefully. Have a high-protein breakfast and fruit and nuts at snack-time.

5. Take no ALCOHOL or CIGARETTES.

6. Take no flavourings, colourings or additives (i.e. 'junk' foods). Take no processed foods, white flour, preserved, smoked, salted, canned or pickled foods (e.g. bacon, beef-stock cubes, ham, pickled herrings, smoked haddock, kippers, sausages, etc.).

7. Take no caffeine, tannin, chocolate or instant drinks.

8. Limit yourself to only four eggs and $4 \mathrm{oz}$ of cheese per week.

9. Take cold-pressed, unrefined oils, e.g. sunflower, safflower, sesame and apricot kernal. Use these sparingly -3 consecutive days on, 4 consecutive days off.

I0. Take no white sugar (beet), brown sugar (cane), honey, treacle, molasses or syrups. Use fructose (Cantassium) instead.

II. When possible, try to avoid unnatural chemical air pollutants, avoid fumes from paint, hairdresser shops, nail varnish, perfumes, soft plastics, glue, aerosol sprays, tar, chlorine (bleach), tobacco and heavy traffic.

\section{Important}

DO NOT FAST, ELIMINATE FOOD FROM YOUR DIET, OR TAKE VITAMIN SUPPLEMENTS, UNLESS YOU CONTACT YOUR DOCTOR FIRST.

Thereafter a series of sequential diets was adopted by which major groups of potentially sensitizing foods were excluded in turn. Initially, milk and milk products were excluded, then wheat and grain products, pips and nuts, followed by meat and meat products (i.e. a vegetarian diet). Each group of potential allergens was reintroduced for $5 \mathrm{~d}$ after a $5 \mathrm{~d}$ period of abstinence. The results of each challenge were recorded as were repeated challenges, if no initial reaction was demonstrated. Challenges were taken on an empty stomach, first thing in the morning on the fifth day after exclusion.

Having identified a number of potential allergens, the patients were tested intradermally for reactions to each of the possible foods that had provoked symptoms and also to botanically-or zoologically-related foods. Thus, in a patient allergic to eggs, chicken and other poultry would be suspect. In a patient sensitive to beef, also suspect would be milk, milk products and cheese. In a patient sensitive to strawberries, other members of the Rosacea family could be antigenically similar; thus apples, pears and the common berries, such as raspberry, would have to be considered. 
Intradermal technique. The Standard Bencard Intradermal skin test procedure consists of inducing mild symptoms with an intradermal injection $(0.05 \mathrm{ml})$ of a dilute $(5 \mathrm{ml} / \mathrm{l})$ food extract and then using further I in 5 saline $(9 \mathrm{~g}$ sodium chloride/l) dilutions of the same food extract at 10 min intervals until a dilution is found which gives no reaction. At the injection site a wheal is induced intradermally and the size of the wheal is measured. It is remeasured again $10 \mathrm{~min}$ after injection and any wheals which are blanched, hard or raised are regarded as positive wheals and a weaker dilution is used. The maximum tolerated intradermal dose is used as a treatment four times a day prior to meals. The dose is administered sublingually $20 \mathrm{~min}$ before meals. The patients are given an instruction leaflet concerning their treatment and they are able to dose themselves and restore innocuous foods to the diet.

Selection and order of testing foods. All patients were first tested with the diluents in saline solutions and, thereafter, with the foods which were found to have provoked symptoms in the exclusion and challenge phase of testing.

Double-blind study. In May 1982 patients were invited to co-operate with a double-blind study with no further selection. Those willing to co-operate were given either a placebo or a mixture of antigens. They were asked to take the sublingual treatment labelled either $A$ or $B$ for 2 weeks each. They each knew that either A or B contained the placebo as did the physician. Each placebo solution was prepared with the same proportion of saline to diluent that the antigen mixture contained. An independent, non-food-allergic observer was asked to taste the solutions and he was repeatedly unable to distinguish between solutions $A$ and B. The patients all ate their usual diets during the test. They were, however, asked to contact the physician if they experienced any intolerable adverse effects during the test. All patients were told that if they had such symptoms, after discussion with the physician, they would be able to resume their normal treatment. This reassurance had to be given to elicit their co-operation.

\section{Results}

A total of 280 patients with severe migraine have been studied dietetically, immunologically and with immunotherapy; the results of the dietetic and intradermal investigations are to be published elsewhere.

The results for the double-blind group of eleven patients are given in $T$ able $I$.

\section{Discussion}

A dietary cause has been firmly established in a large proportion of patients with migraine: cheese, orange, chocolate and alcohol are often implicated and the 'tyramine' hypothesis has been postulated to account for this sensitivity. However, these foods may contain other amines; viz octopamine in citrus fruit, phenylethylamine in chocolate and ethanol congeners and histamine-like derivatives in alcoholic drinks. There have been some studies in which tyramine 
Table I. Responses of eleven migraine sufferers to placebo or allergen solutions in a double-blind study

Active

Patient

I

2

3

4

5

6

7

8

9

10

II

\begin{tabular}{|c|c|}
\hline \multicolumn{2}{|r|}{ Active } \\
\hline Solution & Symptoms \\
\hline $\begin{array}{l}\text { A } \\
\text { B }\end{array}$ & $\begin{array}{l}\text { No difference } \dagger \\
\text { Headache } 3 \mathrm{~d} \text { during } \\
\text { menstruation }\end{array}$ \\
\hline B & One migrainous attack \\
\hline $\begin{array}{l}A \\
A\end{array}$ & $\begin{array}{l}\text { No symptoms } \\
\text { No symptoms for } 2 \text { weeks }\end{array}$ \\
\hline B & $\begin{array}{l}\text { No change in usual } \\
\text { condition } \dagger\end{array}$ \\
\hline $\begin{array}{l}\text { A } \\
\text { B }\end{array}$ & $\begin{array}{l}\text { No difference } t \\
\text { Protected }\end{array}$ \\
\hline A & Protected \\
\hline $\begin{array}{l}\text { B } \\
\text { A }\end{array}$ & $\begin{array}{l}\text { No symptoms } \\
\text { No headaches. Mild anxiety } \\
\text { symptoms }\end{array}$ \\
\hline
\end{tabular}

\begin{tabular}{|c|c|}
\hline \multicolumn{2}{|r|}{ Placebo } \\
\hline Solution & Symptoms \\
\hline $\begin{array}{l}\text { B } \\
\text { A }\end{array}$ & $\begin{array}{l}\text { No difference }{ }^{\dagger} \\
\text { Seven headaches (common } \\
\text { migraine) in } 2 \text { weeks }\end{array}$ \\
\hline A & $\begin{array}{l}\text { Severe headaches and nausea } \\
\text { every morning-classical } \\
\text { migraine } \times 3\end{array}$ \\
\hline $\begin{array}{l}\text { B } \\
\text { B }\end{array}$ & $\begin{array}{l}3 \mathrm{~d} \text { Migraine during } 2 \text { weeks } \\
\text { Severe headaches for } 2 \mathrm{~d} \text {. } \\
\text { Abandoned this treatment, } \\
\text { resumed her own treatment }\end{array}$ \\
\hline A & $\begin{array}{l}\text { Not helpful, i.e. headaches } \\
\text { recurred }\end{array}$ \\
\hline B & No difference $t$ \\
\hline$A$ & $\begin{array}{l}\text { Severe headache within } 6 \mathrm{~h} \\
\text { of taking food with allergen } \\
\text { on three occasions }\end{array}$ \\
\hline B & $\begin{array}{l}\text { Slow onset of headaches, } \\
\text { one lasting } 3 \mathrm{~d}\end{array}$ \\
\hline$A$ & Headache $\times 3$ in 2 weeks \\
\hline B & $\begin{array}{l}\text { Headache and anxiety } \\
\text { recurred }\end{array}$ \\
\hline
\end{tabular}

-For details, see p. 244 .

$\lceil$ No headaches.

Table 2. Range of foods yielding antigens or 'active solutions'

$\begin{array}{lll}\text { Wheat } & \text { Yeast } & \text { Fructose } \\ \text { Milk } & \text { Tea } & \text { Egg } \\ \text { Beef } & \text { Cane sugar } & \text { Maize } \\ \text { Chocolate } & \text { Cheese } & \text { Ethanol } \\ \text { Tobacco } & \text { Glycerol } & \text { Corn syrup } \\ \text { Terpene } & \text { Pea } & \text { Apple } \\ \text { Cabbage } & \text { Carrot } & \text { Banana } \\ \text { Potato } & \text { Tomato } & \text { Phenol } \\ \text { House dust } & \text { Honey } & \text { House-dust mite } \\ \text { Mixed beans } & \text { Herring } & \text { Sago } \\ \text { Grass pollen } & \text { Tree pollen } & \text { Mixed threshings } \\ \text { Candida } & \text { Phenol } & \text { Formalin } \\ \text { Chicken } & \text { Sugar-beet } & \text { Strawberry } \\ \text { Plum } & \text { Pork } & \text { Plaice } \\ \text { Wine } & \text { Onion } & \text { Mixed nuts } \\ \text { Chlorine } & \text { Coffee } & \text { Orange } \\ \text { Rice } & \text { Tap water } & \end{array}$


has been prescribed in capsule form and migraine has not been provoked. Other postulates are that either phenylethylamine or phenolated compounds in foods are responsible.

However, for the patients studied here the range of antigens includes foods which do not characteristically contain these substances (Table 2) and it is therefore presumed that the operant factor was not a single biochemical entity but an immunological one. The patients' frequency, duration and severity of migrainous attacks has been shown to be markedly different with placebo compared with active antigen treatment (Table $\mathrm{I}$ ).

This study corroborates the long-held view that migraine is due to food allergy. The immunological mechanisms have yet to be defined but treatment by immunotherapy has been effective in controlling symptoms in the double-blind study.

The author is most grateful to Dr K. Zilkha for permission and encouragement in pursuing this investigation and to Dr J. Brostoff whose help and support for immunological investigations has paralleled the clinical work.

\section{REFERENCES}

Edmeads, J. (1977). Headache 17, 48 .

Goltman, M. A. (1936). J. Allergy 7, 35 1.

Ingvar, D. H. (1976). Hemicrania 7, 2.

Kailin, E. W. \& Hastings, A. (1970). Med. Ann. Distr. Columbia 39, 437.

Miller, J. B. (1976). Trans. Am. Ophthalmalogic Otolaryngologic Allergy 16, 150.

Miller, J. B. (1977). Ann. Allergy 38, 185.

Monro, J. A. (1982). Clin. Immunol. Allergy 2, 137.

Monro, J. A., Brostoff, J., Zilkha, K. \& Carini, C. (1980). Lancet ii, I.

Rapp, D. J. (1978). Med. F. Aust. 1, 571.

Welch, K. M. A. (1976). Headache 16, 160. 